\title{
Information Technology in Teaching and Learning French as a Foreign Language at the University of Jordan
}

\author{
Nahed Emaish, Associate Professor \\ University of Jordan, Department of French, Jordan
}

doi: 10.19044/esj.2016.v12n26p399 URL:http://dx.doi.org/10.19044/esj.2016.v12n26p399

\begin{abstract}
This research aims to investigate to what extent students and professors at the University of Jordan use information technology in teaching and learning French. It also intends to evaluate the effect that IT tools have on the teaching/learning of this language at the Department of French at this university. The study sample was confined to (90) third-year students majoring in French. Another sample included all (8) professors in the department. The research method utilized two questionnaires, one for the professors and the other for students. The data was analyzed by descriptive statistics, and highlighting means and frequencies. The findings revealed that technology is used by the majority of students for such tasks as using online dictionaries, getting information for their projects and assignments and doing power point presentations. These activities play a part in developing their learning of the language. The findings also showed limitations in their interaction with native-speakers, use of social media, movies, and songs in the target language. As for the professors, the answers revealed that information technology is not often used in their courses. And when used, it is limited to e-mails or power-point presentations.
\end{abstract}

Keywords: Information Technology, Foreign Language, Educational Technology

\section{Introduction}

Educational technology is wide spreading, and the use of technology for teaching and learning foreign languages has also expanded rapidly. Many studies investigated the effect of technology on students' achievement and attitudes. Stepp-Greany identified these benefits of technology in the classroom: "increased motivation, improvement in self-concept and mastery of basic skills, more student-centered learning and engagement in the learning 
process, and more active processing, resulting in higher-order thinking skills and better recall". (Stepp-Greany, 2002)

Jordan is an Arab country where English is the first foreign language and French is the second. French is taught in most private schools, in some public schools, and in three private universities as well as three public ones. Lately, a rise in demand for French at university level has been noticed.

It has been subjectively observed that there are difficulties in teaching French at Jordanian schools and universities. The most important problem is teaching methodology. Previous research has indicated that methodologies and educational resources used in Jordan are mainly traditional (e.g., Emaish, 2003).

This research aims to investigate to what extent students and professors use information technology in teaching and learning French at the University of Jordan. It intends to evaluate the effect that tools have on the teaching/learning of this language at the Department of French.

The findings of this research should be useful in improving the methods of French teaching/learning in Jordan. They also help in preparing training programs for professors in the field of technology and syllabus design.

\section{Theoretical Framework:}

Since one of the main objectives of this study is to improve French language learning and acquisition, it is important to take a look at a number of language acquisition theories.

Piaget (1962) and Vygotsky (1978) highlighted the role of the social context in the knowledge construction process (constructivism), and they underlined the importance of peer interaction in cognitive development.

Other theories developed by Krashen (1982) underlined a different type of social interaction in second language acquisition. Krashen (1982) and Echevarria, Vogt, and Short (2013) stressed the importance of using technology and other instruction methods, to improve the motivation of students as well as their competencies in using the language (Diallo, 2014:8).

According to Krashen, acquisition is different from learning. "The result of language acquisition.... is subconscious. We are generally not consciously aware of the rules of the languages we have acquired". (Krashen, 1982: 10) As for the term 'learning', Krashen defines it as "the conscious knowledge of a second language, knowing the rules, being aware of them, and being able to talk about them". (Krashen, 1982: 10).

Krashen (1982) stated that if the learner is not in a learning conducive environment that motivates him to learn and provides him with a comprehensive input and a low filter environment (free of anxiety and boredom), then the learner will be in a pessimistic mood and will not learn. Therefore, using technology tools to motivate students and encourage their 
involvement in the learning process will increase their achievement rate (Diallo, 2014:10).

The usage of computer technology for language learning began in the fifties. The computer was used in three stages Behaviorist CALL (Computer Assisted Language Learning), Communicative CALL and Integrative CALL. The first phase of CALL was based on behaviorist theories of learning which relied on repetitive drilling and practicing.

The second phase started in the seventies with the introduction of the communicative approach, whose proponents thought that rote learning and drills were not conducive to authentic communication and meaningful learning.

As for the Integrative approaches to CALL, they were based on two technological developments: multimedia computers and the Internet (Warschauer, 1996: 4).

In the last decades, task-based approaches have accentuated authentic use of the target language through tasks that link the language to real-life activities. The concept of scaffolding was introduced; it is incorporated through a "teaching strategy consisting of episodes, sequences of actions, and interactions which are partly planned and partly improvised". (Van Lier, 1996: 100)

Studies in the field of CALL have investigated the nature of tasks that could be used in language interaction mediated by technology. New pedagogical approaches and new strategies for CALL Task based language learning were introduced to the classrooms (Chapelle, Guichon, 2012).

The use of mobile devices was also studied; Stockwell (2007) suggested that smart phones "have the potential to become a more integral part of language learning courses as opposed to the more supplemental role often assigned to computer lab". (Pellerin, 2014:5)

The tasks in this new CALL context should lead the learning toward predetermined task outcomes. In his article, Pellerin demonstrated that "the use of mobile technologies such as iPods and tablets contributes to redesigning language tasks and activities by helping young learners to create their own learning environment and meaningful language tasks, as well as self-assess and regulate their language learning process". (Pellerin (2014:1)

\section{Objectives of the study}

The objectives of the study are:

1. To explore the use of IT in learning/teaching French language at the University of Jordan.

2. To evaluate the effect that IT tools have on the teaching/learning of this language. 
3. To ultimately contribute to improvement of the acquisition and teaching of French at the University.

\section{Research Method:}

Two questionnaires were used, one for professors and the other for students. In the process of development of the questionnaires, some of the questions that are used in the study were adopted from a survey conducted by EDUCAUSE center for applied research about student information technology use and skills in higher education (EDUCAUSE, 2014).

The two questionnaires were validated by a panel of colleagues teaching French in other Jordanian universities and by a sample of students of French who were not expected to be in the experimental group. These students were given drafts of the students' questionnaire to check the comprehensibility of the questions and their relevance to their needs.

The questionnaire was distributed to 90 students; all third year students majoring in French. This group was particularly targeted because it is the time to start extended writing as in research papers and essays.

The second questionnaire was distributed to all the professors teaching in the department ( 8 professors).

\section{Results of the study:}

The study revealed the following results:

\subsection{Students' questionnaire:}

The first question in the students' questionnaire is about the electronic devices that students own. Less than half of the students $(45 \%)$ own a smart phone, One tenth of the surveyed students own a personal desktop computer, more than one third of them have a personal laptop computer and one tenth own IPAD. Figure (1) shows the results.

Figure 1: Electronic Devices that students own

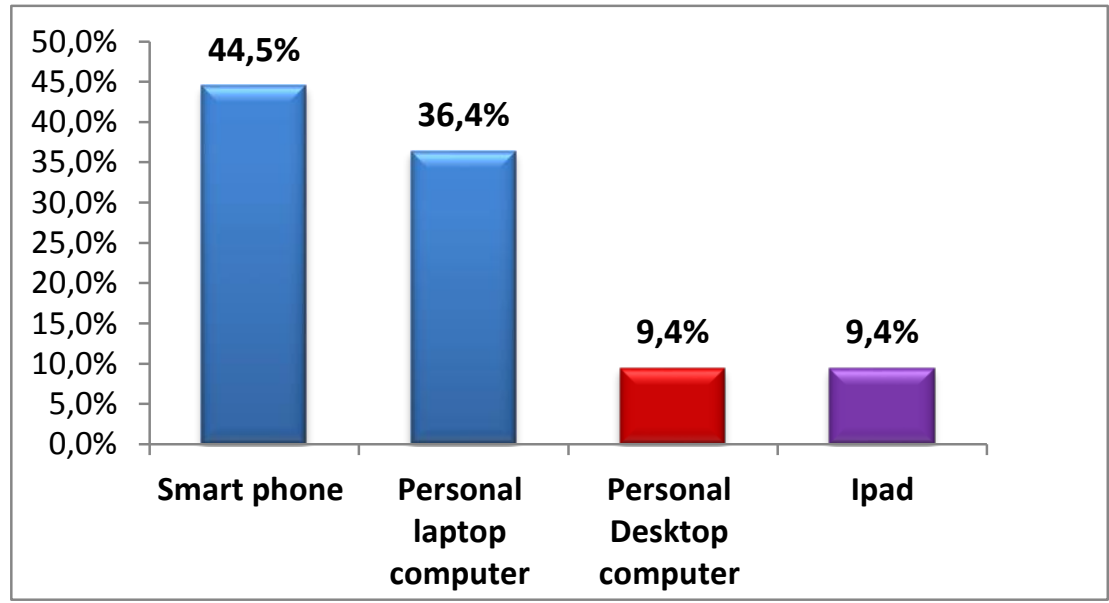


When asked about the devices they use in order to help them learn more about French, over half of them answered that they use personal laptop computer (51\%), while 36\% use Smart Phones and 9\% use IPad.

Figure 2: Devices students use to improve French learning

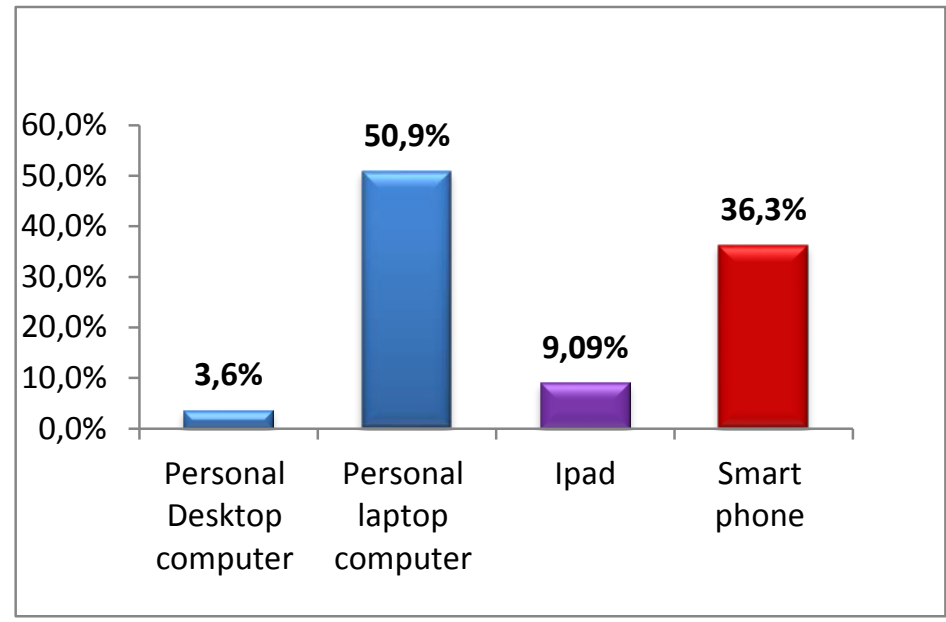

As for their preference regarding the use of technology in the class, almost third of the students prefer taking classes with moderate level of technology. More than fifth of the students indicate preference for classes that use no information technology or limited technology features respectively. (26\%) of students like to take classes using technology extensively. Figure (3) show these results.

Figure 3: Students preferences in regards to the use of technology in classes

I prefer taking classes that are delivered entirely online with no required face-to-face interactions.

I prefer taking classes that use technology extensively (e.g., class lecture notes online, computer simulations, PowerPoint presentations, streaming video or audio...

I prefer taking classes that use a moderate level of technology (e.g., e-mail, several power-point presentations, some online activities or content).

I prefer taking classes that use limited technology features (e.g., e-mail to instructors and limited use of PowerPoint in class)

prefer taking classes that use no information technology

\section{$14,2 \%$}

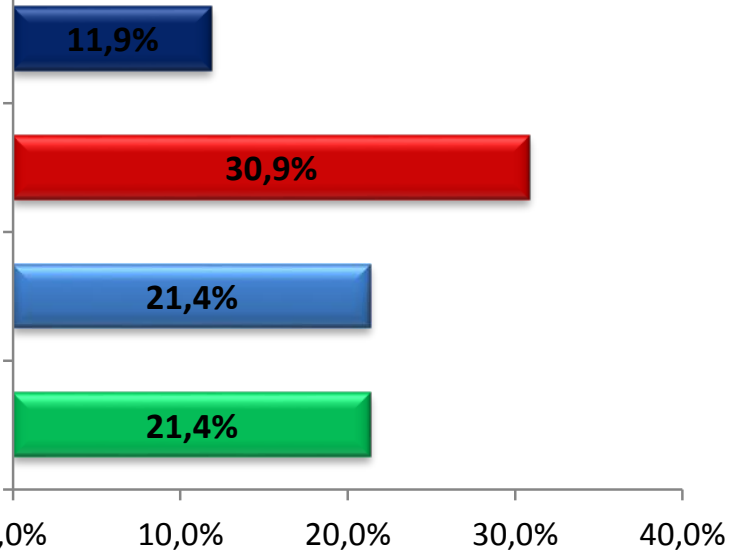


As to the extent that the use of IT is helping students learning the language, the majority think that using IT is helpful to various degrees (large, moderate), while only less than fifth think it's helpful to a small degree. See figure (4).

Figure 4: The extent to which the use of information technology in classes helping students learning the language

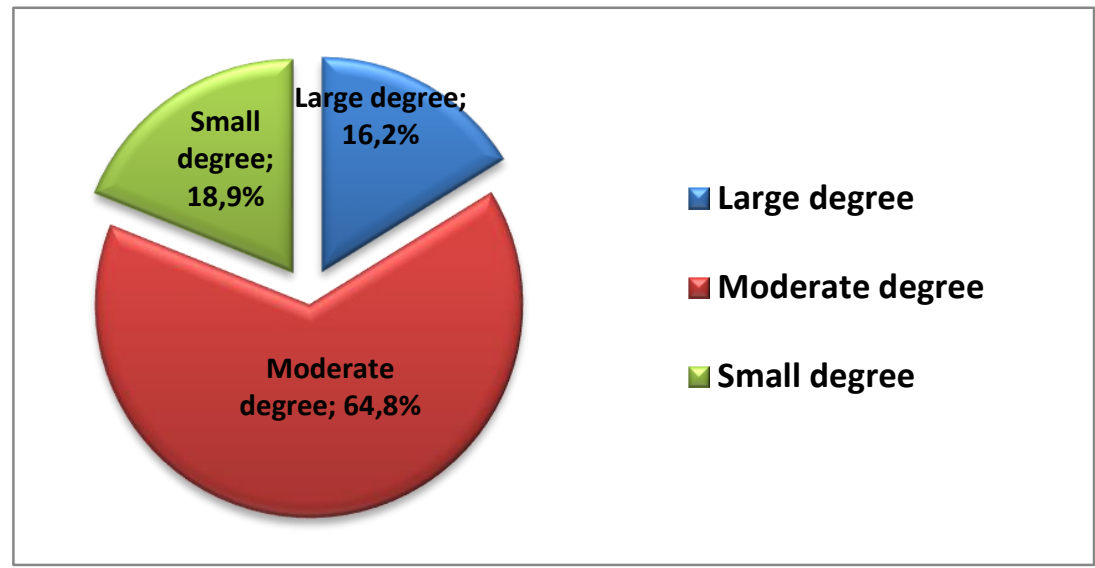

When students were asked about the ways they use information technology, third of the students use online dictionaries $(33 \%)$, followed by looking for information for assignments and projects (23\%), doing power point presentations (17\%), followed by getting assignments back from professor. A minority of students use technology to share materials with their colleagues or turn in assignments online. Figure (5).

Figure 5: The main purpose student uses Information Technology

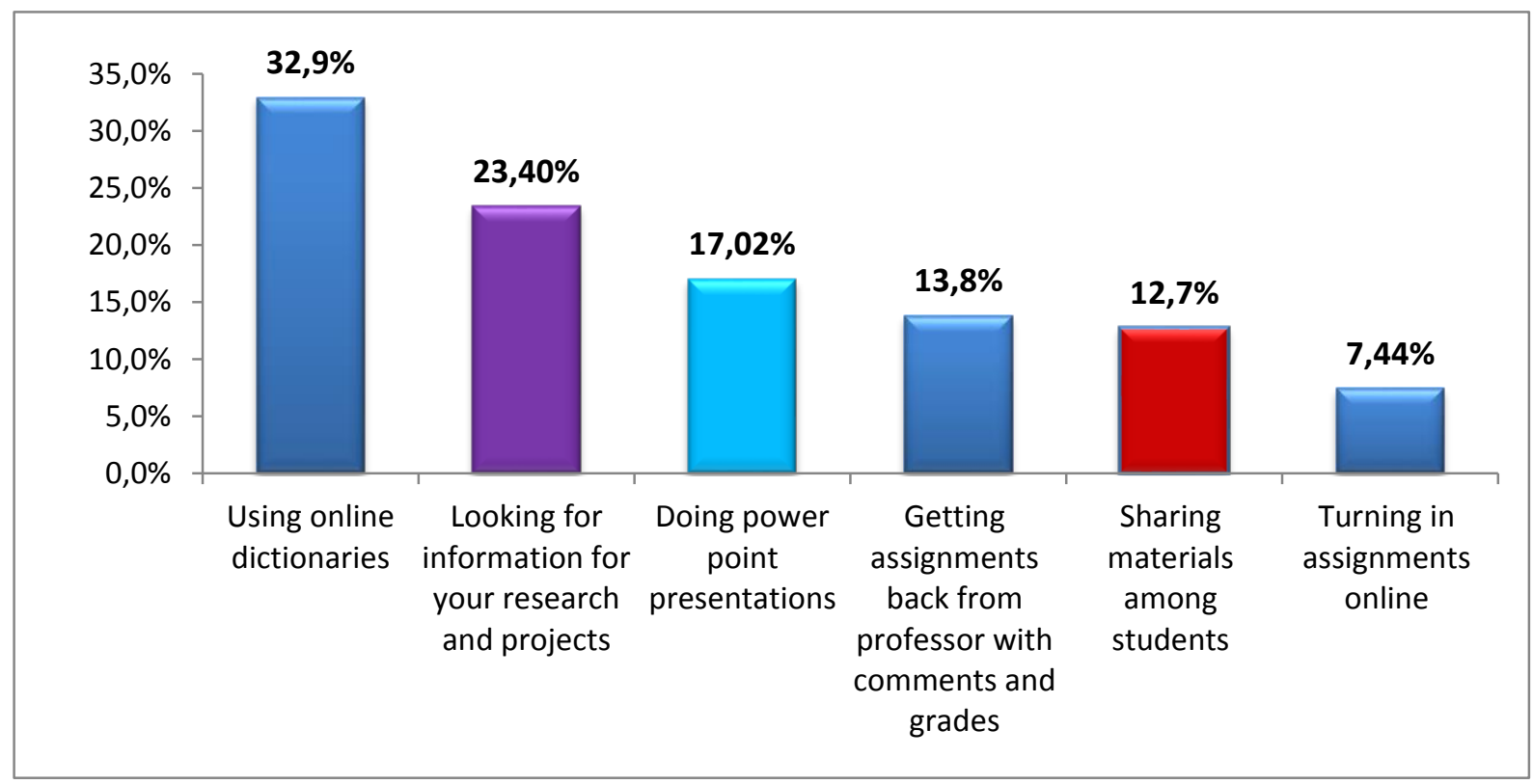


The most valuable benefit from using information technology in the class for the students is saving their time, followed by improving their learning. Only, $4 \%$ of the students think it is convenient and $21 \%$ found that there are no benefits from using information technology in the class.

Figure 6: Students benefits from the use of information technology in the classes

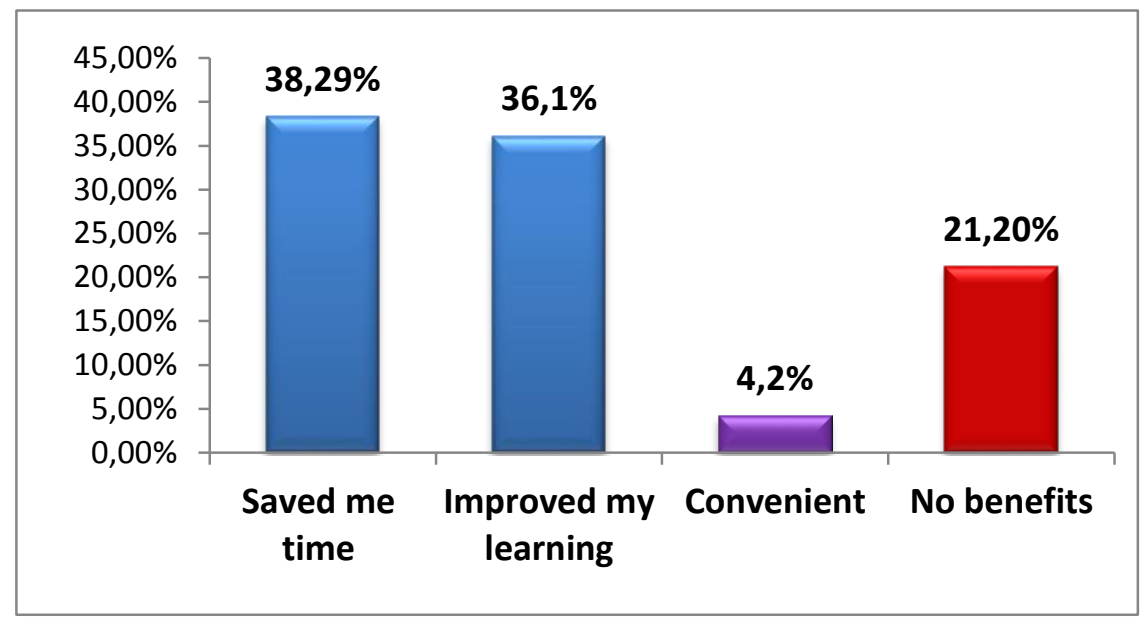

As for the barriers that prevent students from using information technology, half of the students reveal that there are no barriers (50\%), while $20 \%$ don't have the necessary skills to use this technology, with only $11 \%$ indicating that it's too expensive. Figure (7).

Figure 7: Barriers (if any) that prevent students from using information technology in the class work

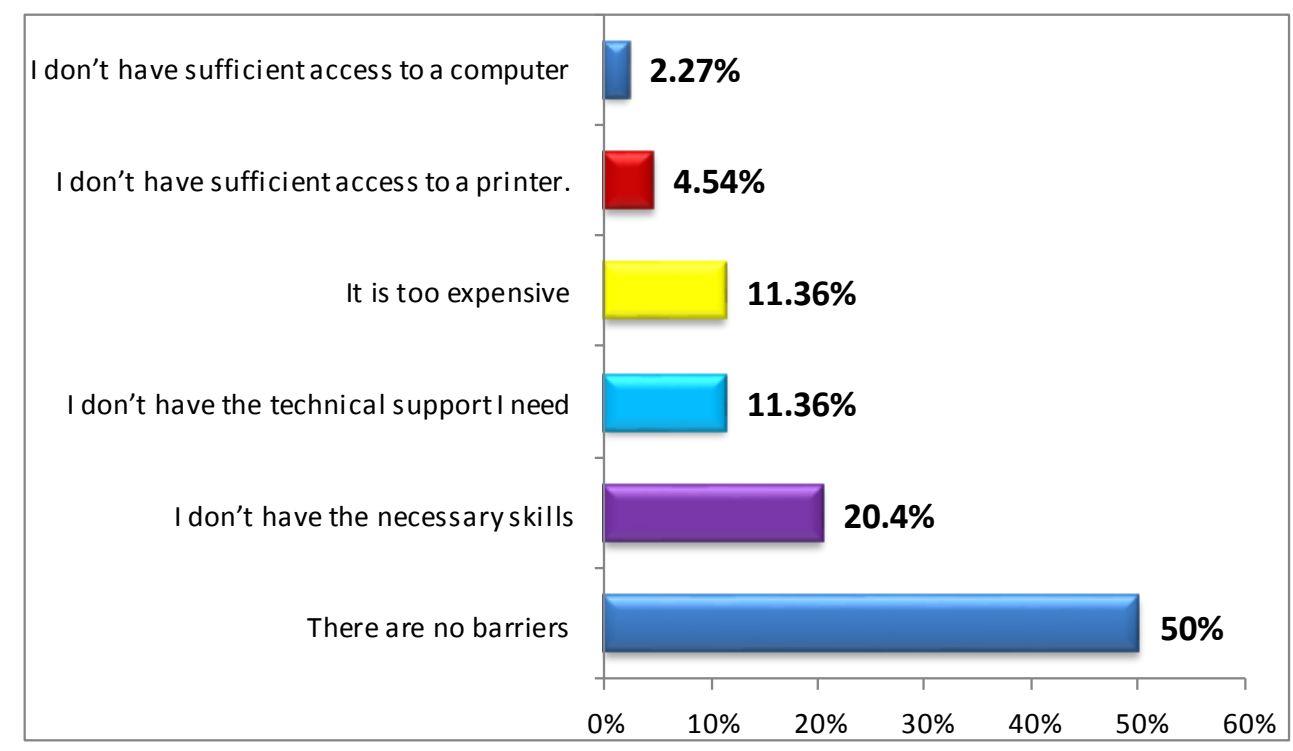




\subsection{Faculty members' questionnaire:}

The questionnaire was distributed to eight professors teaching French at the Department of French language at the University of Jordan. The results reveal that all but one, use sometimes electronic tools when teaching their courses.

When planning a course, five professors out of eight, consider using electronic tools to help students achieve the course educational goals.

All professors think that using electronic tools is important in helping students learn the course content to various degrees.

In answer to the question: In which way do you use IT in teaching?

All professors use email to communicate with students, three of them use power point presentations, and only one professor has Facebook groups.

Regarding the difficulties that they encounter when using electronic tools, most said the lack of available tools followed by only two who mentioned the lack of time as being a barrier.

\section{Findings and results:}

The answers show that a big number of students own smart phones and personal laptops, this explains the answers to the question in which they revealed that they mainly use their own laptops and smart phones when they study. The computers provided by the University are not used much.

The answers show that a good percentage of students prefer taking classes that use a moderate level of technology, followed by students who prefer limited or no use of technology in the classes. Similarly, a big number of students revealed that the use of information technology in classes helped them moderately in learning the language.

This might be attributed to the fact that the use of technology in classes is limited at the Faculty of Foreign Languages due to the few numbers of classrooms equipped with technology tools or devices.

The answers also showed that using online dictionaries and looking for information useful for assignments and projects are the main benefits of IT. It is important to mention here that activities such as following an e-course are not mentioned because such courses do not exist at the faculty.

None of the surveyed students use social media to interact with native speakers of French.

The most valuable benefit from using information technology for the students is saving time, followed by improving their learning.

As for the barriers in using information technology, half of the students thought that there were no barriers.

This research have shown that the majority of students use information technology primarily to save time and to improve their language learning. They use it to locate information for projects and assignments and to learn the 
meaning of vocabulary items in online dictionries. Information technology as far as students are concerned is used on students" private time and using their privately owned smart phones and laptops.

As for the professors, the answers show that information technology is not often used in their classes. Half of them think that using electronic tools is very important in helping the students learn the course content. Meanwhile, the other half thinks that it is moderately important.

The answers show that the usage of IT by the majority of professors is limited to email communication with students. Few only, use power point presentations.

Professors do not give students tasks and activities that require the use of IT devices. The new approaches and strategies for CALL Task based language learning are not yet used in UJ classrooms.

The answers show also that not all professors are aware of the importance of IT in their classes. But for those who want to use IT, there are several constraints such as the lack of classrooms equipped with technology tools and the lack of ongoing training for professors to integrate new media in the teaching process. Courses about the importance of the use of IT in teaching second and foreign languages should be proposed to the professors at the University.

\section{Conclusion}

Information technology is part of the everyday life of students of French as a foreign language at the University of Jordan. They use it for communication, socialization, and entertainment. Information technology is an integral part of the lives of all young people in Jordan. Therefore, IT use by students of French as a foreign language is quite in order. Not to use it for educational purposes would be an anomaly that would require explanation.

This research shows that teachers of French are not utilizing IT to its full potential.

As it is mentioned in the paper, several constraints prevent them from using technology such as, the lack of classrooms equipped with technology tools and the lack of ongoing training for our professors to integrate the new media in the teaching process.

The huge variety of purposes of IT use to improve the learning/teaching of a language should be introduced by providing training courses to both students and professors that could be organized by the Faculty. More classes should be equipped with IT tools to enhance language learning and engage students in their learning process. 


\section{References:}

Chapelle, C. (1997). CALL in the year 2000: Still in search of research paradigms? Language Learning \& Technology, (1), 19-43.

Chapelle, C. (2001). Computer applications in second language acquisition: Foundations for teaching, testing, and research. London: University Press.

Diallo, A. (2014). The use of technology to enhance the learning experience of ESL students. Master Thesis. Concordia University-Portland

Echevarria, J. Vogt,M. (2013). Making content comprehensible for English learners: The SIOP model ( $4^{\text {th }}$ ed.). Boston, MA: Pearson/Allyn \& Bacon.

Ede, O. S. \& Ogiegbaen, S.E. Assessment of the use of educational technology by social studies teachers in secondary schools in western. University of Benin. Retrieved on the January, $2^{\text {nd }}, 2015$ from http://www.ascilite.org.au/ajet/e-

jist/docs/vol8_no1/commentary/assess_ed_tech.htm

Emaish, N. (2003). The commun European framework in non European countries (the case of Jordan). Dialogues and cultures. Proceedings of the conference The Commun European framework: a global reference. 156-160. EDUCAUSE. (2014). Student information technology use and skills in Higher Education. Retrieved on January, $4^{\text {th }}$ from https://net.educause.edu/ir/library/pdf/si/esi04d.pdf

Guichon, N. (2012). Vers l'intégration des TIC dans l'enseignement des langues. Paris: Didier.

Kern, R. (1995). Restructuring classroom interaction with networked computers. Effects on quantity and quality of language production. Modern Language Journal. 457-476.

Krashen, S.D. (1982). Principles and practice in Second language Acquisition. Oxford: Pergamon.

McDougald, J.( 2009). The use of information and communication technology (ICT), EFL classroom as a tool to promote L2 (ENGLISH) among non-native pre-service, English teachers. The University of Leon. Retrieved on March, $17^{\text {th }}$ from http://www.academia.edu/238178/

Pellerin, M. (2014). Language tasks using touch screen and mobile technologies: Reconceptualizing Task-Based CALL for Young Language Learners, CJLT RCA, 40(1), p. 1-23.

Pescheux, M. (2007). Analyse de pratique enseignante en FLE. Paris: L'Harmattan.

Piaget, J. (1962). Comments on Vygotsky's critical remarks concerning the language and thought of the child, and judgment and reasoning in the child. Retrieved on March 17th from http://marxiste.org/archive/vygotsk/works/comment/piaget.htm 
Puren, C. (1998). Didactique scolaire des langues vivantes étrangère en France et didactique française du français langue étrangère. Etude de linguistique appliquée, 111( jul/sep), 359-383.

Salaberry, R. (2002). The use of technology for second language learning and teaching. The Modern Language Journal, 85, 39-56.

Sandholtz, J. H, Ringstaff, C., \& Dwyer, D. C. (1997). Teaching with technology: Creating student-centered classrooms. New York: Teachers College Press.

Sayers, D. (1993). Distance team teaching and computer learning networks. TESOL Journal, 3(1), 19-23.

Stepp-Greany. J. (2002). Student perceptions on language learning in technological environment implications for the new millennium. Language Learning \& Technology, 6, 165-180. Retrieved on April $2^{\text {nd }}$ from http://lit.msu.edu/vol6num1/steppgreany/

Sockwell, G. (2007). Vocabulary on the move: Investigating an intelligent mobile phone-based vocabulary tutor. Computer Assisted Language Learning, 20, 365-383.

Van Lier, L. (1996). Interaction in the language curriculum: Awareness, Autonomy, and Authenticity. London: Longman.

Vygotsky, L. (1978). Interaction between learning and development.In M. Cole, V. John-Steiner, S. Scribner, \& E. Souberman(Eds.), Mind in society: The development of higher psychological processes. Cambridge, MA: Harvard University Press..

Warschauer, M. (1996). Computer Assisted Language Learning: an introduction. In Fotos S. (ed.) Multimedia language teaching, p. 3-20. Retrieved on March $20^{\text {th }}$ from http://www.ict4lt.org/en/warschauer.htm 